\title{
O PRESENTE DOS CANOEIROS DE ITAPUÃ
}

\author{
Fernando Firmo ${ }^{1}$
}

Itapuã de águas verdes e cristalinas, cantada em prosa e verso por Vinícius de Moraes, seus antigos e novos baianos - na primeira segunda-feira após a festa de lemanjá no Rio Vermelho de Jorge Amado - é palco de um dos mais belos presentes à rainha das águas. Relembrando a memória de seus ancestrais, a geração atual de canoeiros, vai ao mar agradecer a majestosa rainha, utilizando canoas tradicionais de vinhático e fazem todo o trajeto da praia ao local marcado para se lançar os presentes no remo: agradecem o ano que passou e pedem fartura no por vir. Estas Canoas, para estes homens, são pessoas com nome próprio, memórias, historicidades, estão ativas nas redes de parentesco, possuem necessidades materiais e espirituais. Compartilham alegrias e tristezas na lida diária com o mar, e a elas, neste evento, é oferecida a primeira oração. Não é o pescador que é eleito para levar a imagem de lemanjá e liderar o Coletivo, e sim, a Canoa mais vistosa, ou como dizem localmente, a Canoa com mais "conceito", categoria nativa que engloba questões estéticas (e outras de ordem material), assim como questões morais, pois o valor de uma Canoa é dado pelas histórias e historicidades confeccionadas a partir dela, narrando sua qualidades (coragem, conhecimento, destreza, força, sagacidade) em eventos cotidianos ou extraordinários. O ensaio fotográfico que lhes apresento é fruto de intensas pesquisas etnográficas sobre festejos populares que não recebem a atenção dos meios de comunicação de massa e não fazem parte do circuito de festas populares da Bahia cotejados pelo turismo e pelas políticas culturais. Optei pelo formato preto e branco, valorizando silhuetas, no intuito de realçar e mostrar a beleza e poética desses homens e suas canoas, levando oferendas, no final da tarde, depois de um dia de trabalho no mar.

${ }^{1}$ Professor Adjunto - Departamento de Antropologia e Etnologia - UFBA 


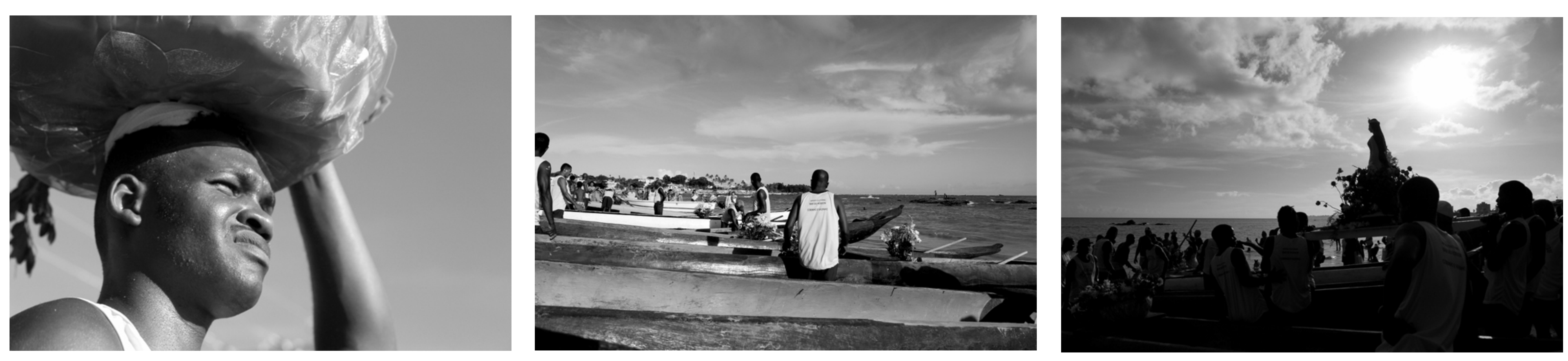



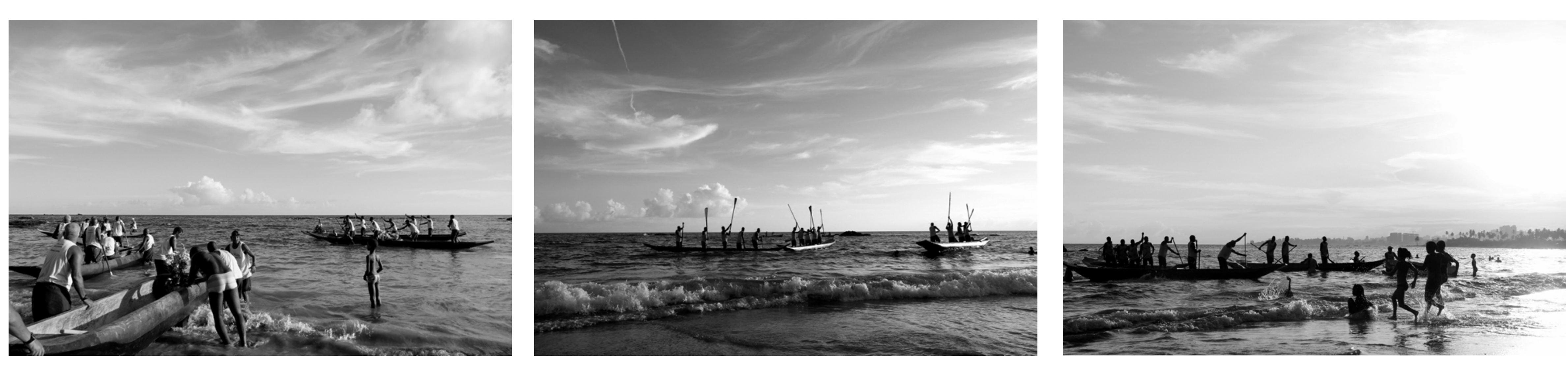